FOLIA POMERANAE UNIVERSITATIS TECHNOLOGIAE STETINENSIS

Folia Pomer. Univ. Technol. Stetin., Oeconomica 2017, 333(86)1, 43-50

Agnieszka MALKOWSKA, Arkadiusz MALKOWSKI ${ }^{1}$

\title{
EKSPORT JAKO CZYNNIK ROZWOJU WOJEWÓDZTW WSCHODNIEGO POGRANICZA POLSKI
}

\section{EXPORTS AS A FACTOR IN THE DEVELOPMENT OF POLAND'S EASTERN BORDERLAND}

Katedra Gospodarki Światowej i Transportu, Uniwersytet Szczeciński w Szczecinie ul. Cukrowa 8, 71-004 Szczecin, e-mail: agnieszka.malkowska@wzieu.pl

${ }^{1}$ Katedra Marketingu, Zachodniopomorski Uniwersytet Technologiczny w Szczecinie ul. Żołnierska 47, 71-210 Szczecin, e-mail: amalkowski@zut.edu.pl

\begin{abstract}
Summary. The article explores the issues of foreign trade with a particular focus on exports. The research covers Poland's eastern borderland, ranging over Podlaskie, Lubelskie and Podkarpackie Voivodeships. The purpose of the research is to describe and analyze exports in the peripheral regions located directly on the eastern border of Poland, and to assess the significance of exports for the development of the area concerned. In the research, the author uses the statistical data analysis method and the descriptive method with elements of deductive reasoning. The studies have shown a growth in commodity exports between 2010 and 2013, and an increasing openness of the economies of the voivodeships concerned to foreign contracts. Despite this, exports have little significance for these economies. Therefore, exports may not be treated as the only factor that determines this area's social and economic development or that will bridge the developmental gap between this and other regions of Poland and the EU. The regions of Poland's eastern borderland are poor at utilizing their geographic location for the purposes of trading with foreign markets.
\end{abstract}

Słowa kluczowe: handel zagraniczny, eksport towarów, polskie pogranicze wschodnie, rozwój społeczno-gospodarczy, region przygraniczny.

Key words: foreign trade, eksports of goods, poland's easter borderlnd, socio-economic development, border region.

\section{WSTĘP}

Jest wiele czynników rozwoju społeczno-gospodarcze, jednak ich dostępność i znaczenie są zróżnicowane w odniesieniu do poszczególnych regionów. Położenie geograficzne obszarów przygranicznych z jednej strony decyduje o ich peryferyjności i niższym poziomie rozwoju, z drugiej strony daje możliwość prowadzenia współpracy transgranicznej, w tym współpracy gospodarczej obejmującej wymianę handlową (Malkowska 2013). Obszary peryferyjne charakteryzują się zazwyczaj bardzo niekorzystnymi cechami społeczno-ekonomicznymi (Malkowski 2013; Malkowska 2014). Liberalizacja wymiany handlowej, rozwój systemów logistycznych w skali międzynarodowej to szanse dla regionów przygranicznych (Malkowski i Malkowska 2014).

Problematyka handlu zagranicznego jest w literaturze szczegółowo analizowana, jednak koncentruje się głównie na całościowym ujęciu eksportu i importu w skali kraju. Tymczasem 
problematyka handlu zagranicznego jest niezwykle istotna także z punktu widzenia regionów, które przecież także konkurują między sobą. Jednak, jak podkreśla Golejewska (2012), w przeciwieństwie do związku między eksportem a wzrostem gospodarczym na poziomie kraju, wpływ handlu na zróżnicowanie regionalne nie jest tak oczywisty. Chociaż badania potwierdzają, że działalność eksportowa może prowadzić do wzrostu produktywności w regionie w wyniku wykorzystania korzyści skali i związanej z tym specjalizacji pracy oraz transferu technologii. Istotne znaczenie dla wzrostu gospodarczego regionu może mieć również dywersyfikacja eksportu (Golejewska 2012).

Celem artykułu jest charakterystyka i analiza eksportu województw wschodniego pogranicza Polski w ujęciu wartościowym, a także ocena jego znaczenia dla rozwoju regionu.

\section{MATERIA I METODY}

Zakres terytorialny badań obejmuje trzy przygraniczne województwa, tj.: podlaskie, lubelskie i podkarpackie. Jest to obszar naturalnie spójny, położony przy zewnętrznej granicy Unii Europejskiej i cechujący się peryferyjnością. Przedmiotem badań niniejszych był handel zagraniczny, a w szczególności eksport, wybranych województw, które tworzą wschodnie pogranicze Polski. W pracy eksport rozpatrywano w wąskim znaczeniu, tzn. wyłącznie jako sprzedaż za granicę towarów.

Wybór obszaru badań podyktowany był chęcią weryfikacji hipotezy badawczej, że handel zagraniczny może być istotnym czynnikiem rozwoju obszaru wschodniego pogranicza Polski. W powszechnej świadomości jest to obszar o niedostatecznym poziomie rozwoju gospodarczego, w którym nastąpiła kumulacja niekorzystnych zjawisk społecznych i gospodarczych. Typowo rolniczy charakter obszaru i silne powiązanie z rynkami wschodnimi spowodowało, iż w ostatnich latach został on w szczególny sposób dotknięty niekorzystnymi skutkami geopolitycznych zawirowań między Polską a Rosją.

Zakres czasowy badań uwarunkowany został dostępnością jednorodnych danych statystycznych; obejmuje lata 2010-2013. W artykule wykorzystano głównie informacje faktograficzne GUS oraz dane Centrum Analitycznego Administracji Celnej, opublikowane w rocznikach statystycznych: Gospodarka Morska. Przegląd Statystyczny. Jednakże dane dotyczące handlu zagranicznego w województwach publikowane są w nich dopiero od 2010 roku. W momencie oddawania artykułu do druku dane z roku 2014 nie były jeszcze dostępne.

W pracy wykorzystano metodę analizy danych statystycznych oraz metodę opisową z elementami wnioskowania dedukcyjnego. W prezentacji wyników badań wykorzystano również technikę tabelaryczną oraz graficzną (ryciny).

\section{WYNIKI}

Analiza znaczenia eksportu w rozwoju województw pogranicza wschodniego wymaga w pierwszej kolejności przedstawienia ogólnej charakterystyki całej wymiany handlowej. Prezentacja danych dotyczących wartości eksportu, importu oraz salda obrotów handlowych stanowić będzie punkt wyjścia do dalszych rozważań (zob. ryc. 1). 


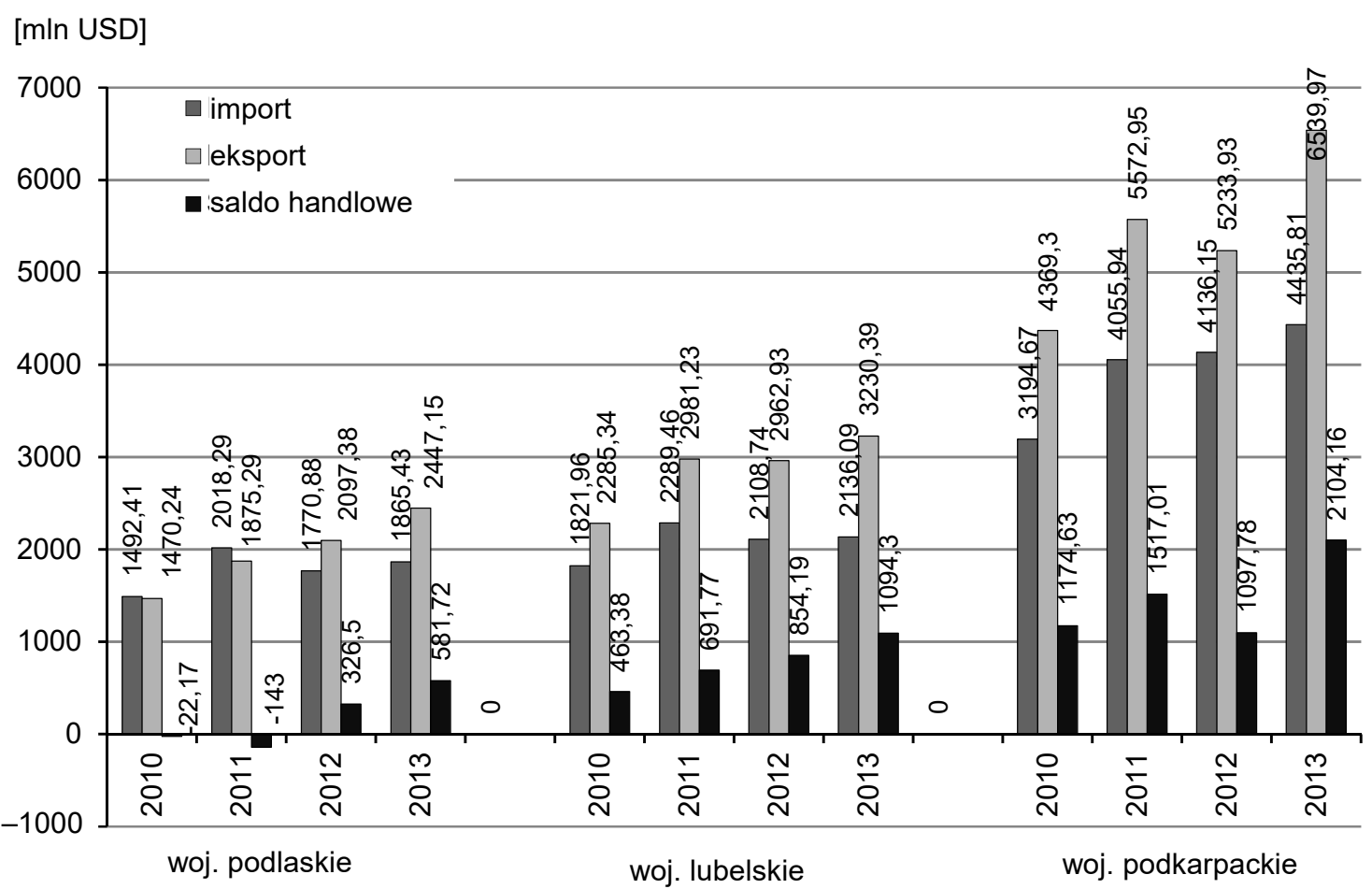

Ryc. 1. Obroty towarowe województw pogranicza wschodniego w latach 2010-2013

Źródło: opracowano i obliczono na podstawie danych Centrum Analitycznego Administracji Celnej.

W latach 2010-2013 łączny eksport badanych województw pogranicza wschodniego wzrósł z 8,1 mld USD do 12,2 mld USD, czyli o ponad $50 \%$. W ciągu czterech analizowanych lat we wszystkich badanych regionach nastąpił wzrost wartości eksportu, przy czym największy odnotowano w województwie podkarpackim - o 2,2 mld USD, a najmniejszy w województwie lubelskim - o 0,9 mld USD. W roku 2013, w porównaniu z rokiem 2010, w poszczególnych jednostkach wzrost eksportu był znaczny; wynosił: 66,4\% w województwie podlaskim, 49,7\% w województwie podkarpackim oraz $41,4 \%$ w województwie lubelskim.

Analizując dane w ujęciu łańcuchowym, należy zauważyć coroczne wzrosty wartości importu w województwie podkarpackim oraz okresowe spadki w pozostałych regionach. Jednakże w roku 2013 we wszystkich badanych jednostkach nastąpił wzrost importu, w odniesieniu do roku bazowego, tj. 2010. Największy wzrost odnotowano w województwie podkarpackim - o 1,2 mld USD (38,9\%), następnie w województwie podlaskim - o 0,4 mld USD (25\%) oraz w województwie lubelskim - o 0,3 mld USD (17,2\%).

W badanym okresie saldo obrotów handlowych z zagranicą województw podkarpackiego i lubelskiego było dodatnie. Podkreślić należy, że w latach 2010-2013 wzrosły one odpowiednio o 79 i 136\%. Jedynie w roku 2010 i roku 2011 w województwie podlaskim odnotowano ujemne saldo obrotów towarowych z zagranicą. Mimo tych spadków w roku 2013 saldo woj. podlaskiego wzrosło o $78 \%$, w stosunku do roku poprzedniego. Można więc przyjąć, że regiony pogranicza wschodniego osiągają dość trwałą nadwyżkę w tym zakresie. Warto podkreślić, że jest to sytuacja odwrotna do sytuacji w kraju; w latach 2010-2013 bilans handlowy Polski był zawsze ujemny.

Dane dotyczące handlu zagranicznego trzech województw pogranicza wschodniego obrazują, że najbardziej aktywny w wymianie towarów z zagranicą jest region podkarpacki. 
Z kolei województwo podlaskie cechuje się najgorszymi wynikami eksportu, importu i salda obrotów handlowych. Należy jednak podkreślić, iż we wszystkich badanych województwach obserwuje się rozwój eksportu. Szczegółowe informacje, dotyczące struktury towarowej i geograficznej badanych województw, przedstawiono w tab. 1.

Tabela 1. Struktura towarowa i geograficzna eksportu województw polskiego pogranicza wschodniego

\begin{tabular}{|c|c|c|c|}
\hline Wyszczególnienie & Województwo podlaskie & Województwo lubelskie & Województwo podkarpackie \\
\hline $\begin{array}{l}\text { Struktura towarowa } \\
\text { eksportu }\end{array}$ & $\begin{array}{l}\text { przetwory mleczarskie } \\
\text { przetwory rybne } \\
\text { urządzenia służące do } \\
\text { podgrzewania wody } \\
\text { meble } \\
\text { mięso wieprzowe }\end{array}$ & $\begin{array}{l}\text { owoce i warzywa przetwo- } \\
\text { rzone i zakonserwowane } \\
\text { chemikalia } \\
\text { maszyny dla górnictwa i bu- } \\
\text { downictwa } \\
\text { wyroby stolarskie i ciesiel- } \\
\text { skie dla budownictwa } \\
\text { mięsa świeże i zakonser- } \\
\text { wowane }\end{array}$ & $\begin{array}{l}\text { Sprzęt transportowy, w tym lot- } \\
\text { niczy } \\
\text { drewno i wyroby z drewna } \\
\text { wyroby z gumy i tworzywa } \\
\text { sztuczne } \\
\text { maszyny i urządzenia mecha- } \\
\text { niczne } \\
\text { wyroby z kamienia } \\
\text { ceramika } \\
\text { szkło } \\
\text { artykuły rolno-spożywcze }\end{array}$ \\
\hline $\begin{array}{l}\text { Struktura } \\
\text { geograficzna } \\
\text { eksportu - główni } \\
\text { odbiorcy }\end{array}$ & $\begin{array}{l}\text { Niemcy } \\
\text { Rosja } \\
\text { Białoruś } \\
\text { Litwa } \\
\text { Holandia } \\
\text { Wielka Brytania }\end{array}$ & $\begin{array}{l}\text { Ukraina } \\
\text { Niemcy } \\
\text { Rosja } \\
\text { Białoruś } \\
\text { Francja } \\
\text { Wielka Brytania }\end{array}$ & $\begin{array}{l}\text { Niemcy } \\
\text { USA } \\
\text { Wielka Brytania } \\
\text { Kanada } \\
\text { Ukraina }\end{array}$ \\
\hline
\end{tabular}

Źródło: opracowano na podstawie: Winogrodzki (2014), Gawlikowska-Hueckel i Umiński (2011), Regionalne Obserwatorium Terytorialne (2013).

Oferta eksportowa województw polskiego pogranicza wschodniego wskazuje na dużą różnorodność potencjału wytwórczego regionu oraz duże rezerwy tkwiące w rolnictwie (w tym ekologicznym) i przetwórstwie spożywczym, a także w przemyśle drzewnym i meblarskim, maszynowym, w branży chemicznej oraz w przemyśle lotniczym (woj. podkarpackie). Wpływy z eksportu towarów w badanych latach w większości przewyższają import, a to ma istotne znaczenie dla oceny sytuacji gospodarczej polskiego pogranicza wschodniego.

Uzupełnieniem przedstawionej analizy bezwzględnych wyników badań handlu zagranicznego wybranych województw przygranicznych jest odniesienie do sytuacji w kraju i do innych regionów. Istotny jest w tym wypadku udział badanych jednostek w generowaniu eksportu krajowego oraz analiza tego wskaźnika na tle pozostałych województw.

Łączny udział badanych jednostek pogranicza wschodniego w eksporcie Polski był stosunkowo niewielki i wynosił 5,2\% w roku 2010 i 6\% w roku 2013. Wśród badanych przygranicznych województw największy udział w eksporcie krajowym miało województwo podkarpackie - 2,8\% w roku 2010 oraz 3,2\% w roku 2013. Z kolei najmniejszy udział w sprzedaży za granicę towarów miało województwo - 0,9\% w roku bazowym oraz 1,2\% w roku 2013. Należy zauważyć także, że w badanym okresie udział analizowanych regionów w generowaniu eksportu Polski nieznaczenie wzrosły (tab. 2). 
Tabela 2. Udział województw pogranicza wschodniego w eksporcie Polski w latach 2010-2013

\begin{tabular}{|l|c|c|c|c|}
\hline \multirow{2}{*}{ Rok } & \multirow{2}{*}{$\begin{array}{c}\text { Eksport ogółem } \\
\text { [mln USD] }\end{array}$} & \multicolumn{3}{|c|}{ Udział województw [\%] } \\
\cline { 3 - 5 } & Polska = 100\% & woj. podlaskie & woj. lubelskie & woj. podkarpackie \\
\hline 2010 & 157002,43 & 0,9 & 1,5 & 2,8 \\
\hline 2011 & 188104,93 & 1,0 & 1,6 & 3,0 \\
\hline 2012 & 181446,35 & 1,2 & 1,6 & 2,9 \\
\hline 2013 & 203847,92 & 1,2 & 1,6 & 3,2 \\
\hline
\end{tabular}

Źródło: opracowano i obliczono na podstawie danych Centrum Analitycznego Administracji Celnej.

W 2010 roku wśród wszystkich 16 województw badane jednostki zajmowały odpowiednio miejsca: 11 (woj. podkarpackie), 13 (woj. lubelskie) oraz 14 (woj. podlaskie). Największy udział w eksporcie krajowym miało województwo śląskie; wynosiło ono aż 15,9\%. Z kolei najmniejszy udział w eksporcie ogółem $(1,1 \%)$ miało województwo świętokrzyskie. W roku 2013 tylko województwo podkarpackie zajęło w omawianym rankingu lepszą pozycję (tj. miejsce 9). Z kolei lokata województwa lubelskiego nie uległa zmianie, a województwo podlaskie spadło na miejsce przedostatnie, czyli 15. Liderem w tym zestawieniu było województwo mazowieckie, którego wartość eksportu wynosiła ponad 31,9 mld USD i stanowiła $15,7 \%$ eksportu krajowego. Ostatnie miejsce w rankingu zajęło ponownie województwo świętokrzyskie z wynikiem 1,1\%.

Regiony tworzące wschodnie pogranicze Polski mają więc niewielki udział w eksporcie krajowym. Mimo że we wszystkich trzech badanych województwach eksport w miarę systematycznie rósł, tylko region podkarpacki poprawił swoją pozycję pod tym względem w stosunku do pozostałych regionów Polski.

Do określenia znaczenia eksportu w gospodarce można wykorzystać wskaźniki obrazujące relację wartości eksportu do wartości PKB (tzw. stopa eksportu) oraz relację wartości eksportu do wartości produkcji sprzedanej przemysłu (jako czynnik stymulujący produkcję) - Brzęczek-Nester 2015).

Stopa eksportu wskazuje pośrednio, w jakim stopniu gospodarka jest proeksportowa. Wskaźnik obrazujący relację wartości eksportu względem PKB wzrósł w roku 2013 w stosunku do roku bazowego we wszystkich badanych województwach (o 6,8 pkt proc. w woj. podkarpackim, o 6,3 pkt proc. w woj. podlaskim i o 2,8 pkt proc. w woj. lubelskim). Im wskaźnik ten jest wyższy, tym lepiej dla gospodarki, w związku z czym wzrost stóp eksportu w przypadku analizowanych jednostek należy ocenić pozytywnie. Można mówić o niesystematycznej, lecz rosnącej otwartości gospodarek badanego obszaru. Należy jednak dodać, że analizowany wskaźnik dla Polski był we wszystkich badanych latach zdecydowanie wyższy, co oznacza, że otwartość gospodarki Polski była dużo większa niż otwartość gospodarek pogranicza wschodniego (tab. 3).

Tabela 3. Relacja wartości eksportu względem produktu krajowego brutto (PKB) dla Polski i województw pogranicza wschodniego w latach 2010-2013

\begin{tabular}{|l|c|c|c|c|}
\hline \multirow{2}{*}{ Rok } & \multicolumn{3}{|c|}{ Eksport/PKB [\%] } \\
\cline { 2 - 5 } & Polska & woj. podlaskie & woj. lubelskie & woj. podkarpackie \\
\hline 2010 & 33,5 & 13,3 & 12,0 & 23,5 \\
\hline 2011 & 36,0 & 18,1 & 16,7 & 31,7 \\
\hline 2012 & 37,3 & 18,0 & 14,4 & 26,0 \\
\hline 2013 & 39,0 & 19,6 & 14,8 & 30,3 \\
\hline
\end{tabular}

Źródło: obliczono i opracowano na podstawie danych Centrum Analitycznego Administracji Celnej oraz Banku Danych Lokalnych (https://bdl.stat.gov.pl/BDL/start), GUS (2011-2013) oraz Brzęczek-Nester (2015). 
Relacja wartości eksportu do wartości produkcji sprzedanej przemysłu jest wskaźnikiem informującym o znaczeniu eksportu dla gospodarek. Ukazuje on, jaka część produkcji jest „uruchamiana” poprzez popyt z zagranicy (tab. 4).

Tabela 4. Relacja wartości eksportu względem wartości produkcji sprzedanej przemysłu (PSP) dla Polski i województw pogranicza wschodniego w latach 2010-2013

\begin{tabular}{|l|c|c|c|c|}
\hline \multirow{2}{*}{ Rok } & \multicolumn{4}{|c|}{ Eksport/PSP [\%] } \\
\cline { 2 - 5 } & Polska & woj. podlaskie & woj. lubelskie & woj. podkarpackie \\
\hline 2010 & 33,5 & 26,1 & 27,6 & 42,1 \\
\hline 2011 & 36,0 & 33,4 & 35,5 & 53,8 \\
\hline 2012 & 37,3 & 33,2 & 30,2 & 43,8 \\
\hline 2013 & 39,0 & 35,2 & 30,6 & 51,6 \\
\hline
\end{tabular}

Źródło: obliczono i opracowano na podstawie danych Centrum Analitycznego Administracji Celnej, Banku Danych Lokalnych (https://bdl.stat.gov.pl/BDL/start), GUS (2012, 2014), Brzęczek-Nester (2015).

Znaczenie eksportu w gospodarkach badanych województw, mierzone tym wskaźnikiem, wzrosło w roku 2013, w odniesieniu do roku 2010. Świadczy to o zwiększeniu otwartości gospodarek regionów: podkarpackiego, podlaskiego i lubelskiego oraz o poprawie zdolności do konkurowania na rynkach zagranicznych. Zaznaczyć jednak trzeba, że jedynie w województwie podkarpackim sytuacja pod tym względem jest porównywalna, a nawet lepsza od sytuacji w kraju. Wskaźniki obrazujące relację PSP do eksportu dla regionów podlaskiego i lubelskiego są niższe od obliczonych dla kraju.

Tabela 5. Eksport podmiotów z udziałem kapitału zagranicznego w województwach pogranicza wschodniego w latach 2010-2013

\begin{tabular}{|c|c|c|c|c|}
\hline Rok & 2010 & 2011 & 2012 & 2013 \\
\hline \multicolumn{5}{|c|}{ Województwo podlaskie } \\
\hline $\begin{array}{l}\text { Liczba podmiotów eksportujących z udziałem kapitału } \\
\text { zagranicznego }\end{array}$ & 73 & 70 & 82 & 86 \\
\hline $\begin{array}{l}\text { Udział eksportu towarów podmiotów z kapitałem zagranicznym } \\
\text { w eksporcie towarów ogółem w województwie podlaskim [\%] }\end{array}$ & 24,5 & 17,7 & 24,4 & 21,0 \\
\hline \multicolumn{5}{|c|}{ Województwo lubelskie } \\
\hline $\begin{array}{l}\text { Liczba podmiotów eksportujących z udziałem kapitału } \\
\text { zagranicznego }\end{array}$ & 154 & 159 & 174 & 156 \\
\hline $\begin{array}{l}\text { Udział eksportu towarów podmiotów z kapitałem zagranicznym } \\
\text { w eksporcie towarów ogółem w województwie lubelskim [\%] }\end{array}$ & 44,5 & 27,4 & 36,0 & 36,3 \\
\hline \multicolumn{5}{|c|}{ Województwo podkarpackie } \\
\hline $\begin{array}{l}\text { Liczba podmiotów eksportujących z udziałem kapitału } \\
\text { zagranicznego }\end{array}$ & 170 & 182 & 191 & 217 \\
\hline $\begin{array}{l}\text { Udział eksportu towarów podmiotów z kapitałem zagranicznym } \\
\text { w eksporcie towarów ogółem w województwie podkarpackim [\%] }\end{array}$ & 56,0 & 47,6 & 61,7 & 59,4 \\
\hline
\end{tabular}

Źródło: obliczono i opracowano na podstawie z danych z tab. 2 oraz danych GUS (2011-2014).

Analizując znaczenie eksportu towarów dla polskiego pogranicza wschodniego, warto wskazać także na działalność eksportową podmiotów z udziałem kapitału zagranicznego. Ich łączna liczba na badanym obszarze wzrosła z 397 w roku 2010 do 459 w roku 2013. Jednakże należy zaznaczyć, że udział eksportu podmiotów z kapitałem zagranicznym w eksporcie ogółem poszczególnych województw był zróżnicowany. W przypadku województwa 
podkarpackiego wskaźnik ten był wysoki i zwiększył się z 56\% w roku 2010 do 59,4\% w roku 2013 (dla Polski wskaźnik ten wynosił odpowiednio 60,9\% oraz 58,0\%). W związku z tym mały udział w działalności eksportowej podmiotów z kapitałem krajowym należy uznać za istotny problem eksportu południowej części wschodniego pogranicza.

\section{PODSUMOWANIE}

Obszary peryferyjne charakteryzują się zazwyczaj bardzo niekorzystnymi cechami społeczno-ekonomicznymi. Tak zwana ściana wschodnia Polski jest przykładem obszaru, gdzie ze względów historycznych, politycznych i gospodarczych skumulowanych zostało wiele czynników destymulujących rozwój gospodarczy. Typowo rolniczy charakter, oddalenie od centrów decyzyjnych, niekonsekwencje w realizacji strategii rozwoju tego regionu spowodowały, iż należy on do najsłabiej rozwiniętych obszarów Polski. Otwarcie rynków zagranicznych i potencjał produkcyjny regionu staje się istotną szansą na przezwyciężenie peryferyjności tego obszaru.

Przeprowadzone badania wykazały, że eksport ma niewielkie znaczenie i nie może być traktowany jako jedyna determinanta rozwoju badanych województw i zmniejszenia ich dystansu rozwojowego w stosunku do innych regionów Polski i UE. Jednocześnie przeprowadzone analizy wykazały, że wskaźnik obrazujący relację wartości eksportu względem PKB wzrósł w roku 2013, w stosunku do roku bazowego, we wszystkich badanych województwach. Świadczy to o otwartości gospodarki regionu oraz poprawie zdolności do konkurowania na rynkach zagranicznych. Region wschodniego pogranicza nie wykorzystuje swojego potencjału konkurencyjnego i geograficznego, na co wskazuje niewielki udział w eksporcie krajowym. Niewielka liczba inwestorów zagranicznych i ich mały udział w eksporcie regionu wskazuje, że potencjał prorozwojowy regionu, tkwiący w działalności proeksportowej, nadal nie jest wykorzystany.

\section{PIŚMIENNICTWO}

Bank Danych Lokalnych. GUS, https://bdl.stat.gov.pl/BDL/start, dostęp: kwiecień 2016.

Brzęczek-Nester D. 2015. Polski eksport w latach 1999-2014 - kluczowe tendencje w ujęciach ilościowym, branżowym i geograficznym, w: Globalizacja - gra z dodatnim czy ujemnym wynikiem? Red. B. Drelich-Skulska, W. Michalczyk, M. Domiter. Wrocław, Wydaw. UE Wroc., 19-20.

Gawlikowska-Hueckel K., Umiński S. 2011. Handel zagraniczny województwa lubelskiego, w: Uwarunkowania krajowej i międzynarodowej konkurencyjności województwa lubelskiego. Red.

P. Ciżkowicz, P. Opala. Warszawa, Wydaw. Ernst \& Young, 153.

Golejewska A. 2012. Eksport jako czynnik rozwoju regionalnego. Aspekt teoretyczny. Zarządz. Fin. 1(2), 277.

GUS. 2011-2014. Działalność gospodarcza podmiotów z kapitałem zagranicznym w roku 2010, 2011, 2012 i 2013 . Warszawa, GUS.

GUS. 2012. Rocznik Statystyczny Przemysłu. Warszawa, GUS.

GUS. 2014. Rocznik Statystyczny Przemysłu. Warszawa, GUS.

Instytut Morski w Gdańsku. 2011-2014. Gospodarka Morska, Przegląd Statystyczny 2010-2013. Gdańsk, Instytut Morski.

Malkowska A. 2013. Strategia rozwoju euroregionu Pomerania a budowa konkurencyjnego regionu przygranicznego. Pr. Nauk. UE Wroc. 307, 353-362. 
Malkowski A. 2013. Rola zarządzania strategicznego w budowaniu konkurencyjnego regionu transgranicznego na przykładzie programu operacyjnego współpracy transgranicznej R. Pr. Nauk. UE Wroc. 315(1), 513-522.

Malkowski A., Malkowska A. 2014. Liberalizacja wymiany handlowej w kontekście procesów globalizacji gospodarki światowej. Zesz. Nauk. USzczec. Współcz. Probl. Ekonom., Globalizacja. Liberalizacja. Etyka 8, 131-142.

Regionalne Obserwatorium Terytorialne. 2013. Województwo podkarpackie - inwestycje i handel zagraniczny, http://monitoruj.podkarpackie.pl/Grafika/Menu\%20glowne/Aktualnosci/Opracowania, dostęp: kwiecień 2016.

Winogrodzki W. 2014. Wymiana gospodarcza województwa podlaskiego z zagranicą - stan, perspektywy, zagrożenia, http://rodm-bialystok.pl/wp-content/uploads/2014/12/Wymiana-gospodarcza-woj-podlaskiego-z-zagranica-stan-perspektywy-zagrozenia-WWinogrodzki.pdf, dostęp: kwiecień 2016. 